\title{
Leadership vizsgálat módszertani megalapozása a felsőoktatásban
}

\section{The sustain of the leadership methodology in higher education}

\author{
T. BALLA \\ Debreceni Egyetem Műszaki Kar, btibor@eng.unideb.hu
}

\begin{abstract}
Absztrakt. A jelenlegi felsőoktatási és piacorientált közegben a felsőoktatási intézményeknek is követniük kell a változásokat, melyeket fel kell tudniuk mérni és azokra mielőbb reagálni. A felsőoktatási intézmények vezetőinek olyan személyes képességekkel kell rendelkezniük, amelyek birtokában hozzá tudnak járulni az intézmény eredményességéhez, valamint képesek motiválni az intézmények munkatársait. Jelen tanulmány célja, hogy feltárja milyen mérési modell alkalmazása lehet eredményes a felsôoktatási intézményekben, amely alapján meghatározhatóak azon vezetői kompetenciák, viselkedések, tulajdonságok, amelyek hozzájárulhatnak az intézmény eredményes múködéséhez, valamint a felsőoktatásban tapasztalt versenyben a fennmaradáshoz.
\end{abstract}

Abstract. Higher education institutions have to follow the changes of current higher education and market oriented atmosphere. All these changes have to be measured and probably reacted to. Leaders of higher education instutions should have personal skills, which can contribute to the efficiency therefore they can motivate their colleagues. The aim of this study is to unfold the most effective measuring model to determine the leadership competencies, behaviours, properties, which can contribute to the successful operation and to the subsistence of experienced competition in higher education.

\section{Bevezetés}

A legtöbb leadership definíció a következő fő elemeket hangsúlyozza: befolyásolás, csoport, cél (Bryman, in.: Den Hartog et al., 1997). Az is megállapítható a definíciók alapján, hogy a leadership „a szervezeti erőforrások közül kitüntetetten az emberi erőforrással foglalkozik, és annak képességét jelenti, hogy hogyan tudja a vezető a szervezet tagjait a szervezeti célok megvalósítására befolyásolni, mozgósítani” (Bakacsi, 1996 pp. 150.).

Kutatásomban a leadership szót alkalmazom annak a folyamatnak a megnevezésére, amely során egy egyén másokat a szervezet céljainak elérésére befolyásol, motivál, és képessé tesz cselekvésre (House \& Javidan, 2004). E cél elérésének érdekében a vezetőnek rendelkeznie kell bizonyos készségekkel, képességekkel és tulajdonságokkal, amelyek azonban önmagukban nem jelentenek garanciát a cél elérésére. A tanulmányban a leader és a vezető szót használom a fent említett tulajdonságokkal 
rendelkező személynek a megnevezésére. Külön jelezni fogom, ha a vezető szót manager-i szerepköréhez kapcsolódóan értelmezem.

A világ felsőoktatása - köztük a magyar felsőoktatási rendszer is - óriási változáson ment át az elmúlt két évtizedben (Barakonyi 2009, Hrubos 2006). A hagyományosnak mondott funkciók jelentősen megváltoztak, a kínálati paletta átalakult - mást ígér mind a hallgatóknak, mind az oktatóknak -, különböző szerepet játszik az emberek, a szakmák, a hivatások, valamint a régiók életében (Fábri 2005). A hazai regionális tudomány is egyre inkább a felsőoktatás felé fordul, továbbá egy új tényező, a verseny is megjelent az egyetemek életében. A kínálati oldalon új intézmények jelennek meg (magán, egyházi, nonprofit, külföldi), a keresleti oldalon pedig szakmák, szakmacsoportok jönnek létre, illetve tûnnek el a

„reflektorfényből” (Rechnitzer 2010). A tudást, valamint az innovációt multiplikáló intézmények, szereplők elkezdtek decentralizálódni, egyre inkább integrálódni a helyi, regionális gazdaságokba, melynek következtében ennek a folyamatnak a szerkezetei is az átalakulás szakaszába léptek (Grosz Rechnitzer 2005).

A felsőoktatási intézmények egyre nagyobb szerepet vállalnak az általuk érintett városok és régiók fejlesztésében, ugyanakkor a városok és a régiók is igyekeznek a lehető legtöbbet megtenni a felsőoktatás gazdasági, társadalmi és kulturális fejlődéséért.

A kapcsolatok a közös, elsődleges gazdasági érdekek fokozott felismerése alapján jönnek létre. A felsőoktatásra szánt állami ráfordítások csökkenésével a felsőoktatási intézmények a következő lehetőségek felé fordulnak (OECD 2007):

- globális kutatási és felvételi marketingstratégia helyi támogatása, több helyi hallgatófelvétele;

- a helyi vállalkozásoknak nyújtott tanácsadói és szakmai szolgáltatásokból származó bevételek növelése;

- a helyi környezet közvetett előnyeinek kiaknázása, melyek vonzók lehetnek mind az oktatók, mind a motivált hallgatók számára.

Továbbá ezek hozzájárulhatnak azon törekvéshez is, hogy a kiválóságok mind a hallgatói, mind az oktatói részről helyben maradjanak.

Mindezek mellett belép a felsőoktatásba a versenyképesség fogalma is. Amint az ismert az Európai Felsőoktatási Tér létrehozásának célja az EU versenyképességének fokozása volt. Mostani célkitűzés, hogy az Európai Unió a világ egyik legjobb, egységes, versenyképes, dinamikus és tudásalapú gazdaságává váljon (Losoncz, 2007).

Barakonyi (2009) és Lengyel (2003) a régiók versenyképességére adott leírást adaptálták a felsőoktatásra. A kutatásom szempontjából Barakonyi megfogalmazása áll hozzám közelebb. Ezek alapján „a felsőoktatás versenyképessége a nemzetközi tudáspiacon történő versengésre való készséget jelenti, a pozíció szerzés és tartós helytállás képességét, amit oktatási piacon a hallgatóért való versengésben való sikeres szereplés, az elért tudáspiaci részesedést és jövedelmezőség megtartása és fenntartható növekedése, a felsőoktatási nemzetközi tudományos kutatási tevékenységben, az innováció terén megszerzett pozíció megtartása és erősítése, valamint a 
nemzetközi szabad tőke kutatási megbízásokra, kutatási együttműködési célú bevonására gyakorolt vonzereje jellemez" (Barakonyi 2009).

A környezeti változások hatására a szervezeteknek, így a felsőoktatási intézményeknek is változniuk kell, a változás egyik módja a szervezeti tanulásban rejlik. A szervezeteket (kognitív) értelemben igen erőteljes tanulás jellemzi (új szervezeti rendszerek, új szabályok és eljárások elsajátítása), amely értékrend változással is járhat, és irányát tekintve pozitív. Ez azonban számottevő kihívást támaszt a vezetőkkel szemben és intenzív szervezeti tanulási folyamatok beindítását teszi szükségessé, mely rövid és hosszú távon a versenyképesség fokozását teszi lehetővé (Hámori - Szabó, 2012:55).

A felsőoktatási intézmények sem elszigetelt szervezetek, így a leadership szerepe is meghatározó a versenyképesség növelésében.

\section{Leadership vizsgálati lehetőségek}

A vezetőkkel szemben támasztott elvárások sokat változtak az elmúlt évtizedek alatt. Ma már elvárás velük szemben, hogy olyan személyes képességekkel rendelkezzenek, amelyek birtokában hozzá tudnak járulni az intézmény hatékonyságához, sikeréhez, valamint munkatársaikat képesek motiválni a célok elérésére. Vizsgálataim megkezdése előtt - a vonatkozó szakirodalom tanulmányozásával azon módszereket vizsgáltam, amelyek egyértelmúen alkalmazhatók a felsőoktatási intézmények leadership vizsgálatára. Kutatásaim során arra a következtetésre jutottam, hogy olyan modellt célszerű alkalmazni, amely mind az akadémiai leadership, mind pedig az új struktúrában megjelenő kancellária vezetésére alkalmas lehet. A hazai és nemzetközi szakirodalom áttekintése után úgy vélem, hogy a következőkben ismertetett módszerek kombinációja lehet célravezető: Globe vezetőkkel szembeni elvárás vizsgálat, FET vezetői attitűdök tesztje, valamint az EFQM modell vezetés témakörére vonatkozó kérdések.

\subsection{Globe}

A GLOBE projekt 1991-ben indult, Robert House ötlete alapján, aki azt a célt tűzte ki maga elé, hogy feltárja a nemzeti és szervezeti kultúrák, illetve a vezetés közti kapcsolatot (House, 2002, 2004; Den Hartog, 1997). A kezdeti célkitűzések folyamatosan bővültek, mind a kérdéseket mind pedig a projekt tartalmát és méretét tekintve (Karácsonyi, 2006).

Alapvető célja a kultúraközi összehasonlítások kivitelezése, de alkalmas a kultúra specifikus tényezőket feltáró vizsgálatra is. A kérdőívvel több, mint 62 kultúrát vizsgáltak. A kutatásban közel 170 nemzetközi szakember vett részt, a Koordinációs Team és Robert House professzor irányításával. A kérdőív a társadalmi kultúra, a szervezeti kultúra és a leadership jellegzetességeit vizsgálta.

A GLOBE kérdőívnek két változata van: az egyik az Alfa változat, a másik pedig a Béta. Az alfa változat a szervezeti kultúra és a leadership, az utóbbi a nemzeti kultúra és a leadership kapcsolatát vizsgálja. A kultúrák megnyilvánulásának két aspektusát méri minden egyes dimenzió esetében: a közösségek gyakorlatát (ahogyan a dolgok vannak a szervezetben) leíró változókkal, és a közösségek elvárt értékeit (ahogyan a dolgoknak lenniük kellene a szervezetben) normatív változókkal (Karácsonyi, 
2006). Az Alfa változat a szervezeti, a Béta változat pedig a társadalmi kultúra jellemzőit vizsgálja. Magyarországon a GLOBE projekt módszerét első ízben Bakacsi alkalmazta és tette ismertté (Bakacsi Takács, 1998.).

A leadership blokkjaiban egy-egy vezetői tulajdonságot annak alapján jellemez, hogy egy vezetőt az adott tulajdonság mennyire segít, vagy gátol abban, hogy kiváló vezető legyen. A skála páratlan fokozatú (1-7), így lehetôvé teszi a válaszadónak a semleges válaszadást, vagyis ha nem tud dönteni, akkor választhatja a 4-es skálaértéket. Másrészt a középső érték választása azt is jelentheti, hogy a megállapítás, tulajdonság, vagy magatartásforma átlagosnak tekinthető.

A kérdőív segítségével 112 leadership változó mérhető, amelyeknek a faktoranalízisét Bakacsi és Takács végezte el 1998-ban. Elemzésük alapján öt faktort alakítottak ki. Magas megbízhatóságuk miatt önálló skálaként használták. Az öt faktor a következő: kiskirály, hiteles-participiatív, változásvezető, remete, bürokrata.

A kapcsolódó szakirodalom alapján megállapítható, hogy a GLOBE kérdőívet eddig gazdálkodási szervezetekben, közigazgatási intézményeknél és önkormányzatoknál alkalmazták, de a próbamérések igazolták - bár ezek még nem reprezentatívak-, hogy felsőoktatási intézményekre is alkalmazhatóak.

\subsection{FET}

A vezetői attitűdök tesztje (FET) olyan mérőeszköz, amely alkalmas annak felmérésére, hogy a tesztkitöltő a vezetéshez (leadership) kapcsolható viszonyulásokat, kompetenciákat hogyan múködteti. A teszt alkalmazható a célzott fejlesztés során. A teszt alapkoncepciója: a vezetők múködésében számos olyan közös, meghatározható jellegzetesség van, amely személyes attitűdökhöz kapcsolható. Az attitűdök olyan komplex struktúrák, amelyek kognitív és érzelmi ismeretkészletet hordoznak, amelyekre hatással van az egyén belső szabályrendszere, illetve a szerzett tapasztalatai. Az attitűdök a személy számos viszonyulásában megmutatkoznak: feladatokkal, vezetőkkel, munkatársakkal stb. kapcsolatban.

A vezetői attitűdök teszt a vezetők személyiségét attitűdök rendszerén keresztül közelíti meg.

A teszt kifejlesztésének előkészítetése során azonosítottak olyan közös vonásokat, amelyek a sikeres vezetői működésben relevánsak. Az attitűdök komplex struktúrák, amelyeket kognitív és affektív tényezők befolyásolnak, továbbá hatással vannak rájuk a szervezeti jellemzők, illetve az egyéni élet és vezetői tapasztalatok.

A teszt elvégzése 15-20 percet vesz igénybe, és a következő eredmények állapíthatóak meg. A szoftver a következő vezetői attitűdöket méri:

- Erélyesség

- Asszertivitás.

- Önbizalom

- Higgadtság, lélekjelenlét 
- $\quad$ Nyitottság

- Vezetői dominancia

- Konfrontálódásra való hajlam

- Túlzott érzékenység

- Mentális egyensúly

- Túlterheltség érzet

\subsection{EFQM modell}

EFQM Kiválóság Modell 2013 évben kiadott modelljéből kell kiindulni, de annak is a vezetésre vonatkozó blokkjából. Az intézmények rendszerint számos menedzsment technikát alkalmaznak a működésük során, az EFQM Kiválóság Modell teljes körű áttekintést ad az intézményről, ez alapján a szervezeti önértékelést elvégezve meghatározhatóak azok a fejlesztendő területek, amelyekre a TQM alkalmazása során a minőségfejlesztési projekteket indíthatják az intézmények. Az EFQM modell sikeres alkalmazása három szorosan összefüggő elem segítségével valósítható meg.

A Kiválóság Alapelvek, amelyek bármely intézmény esetében nélkülözhetetlenek a fenntartható kiválóság eléréséhez.

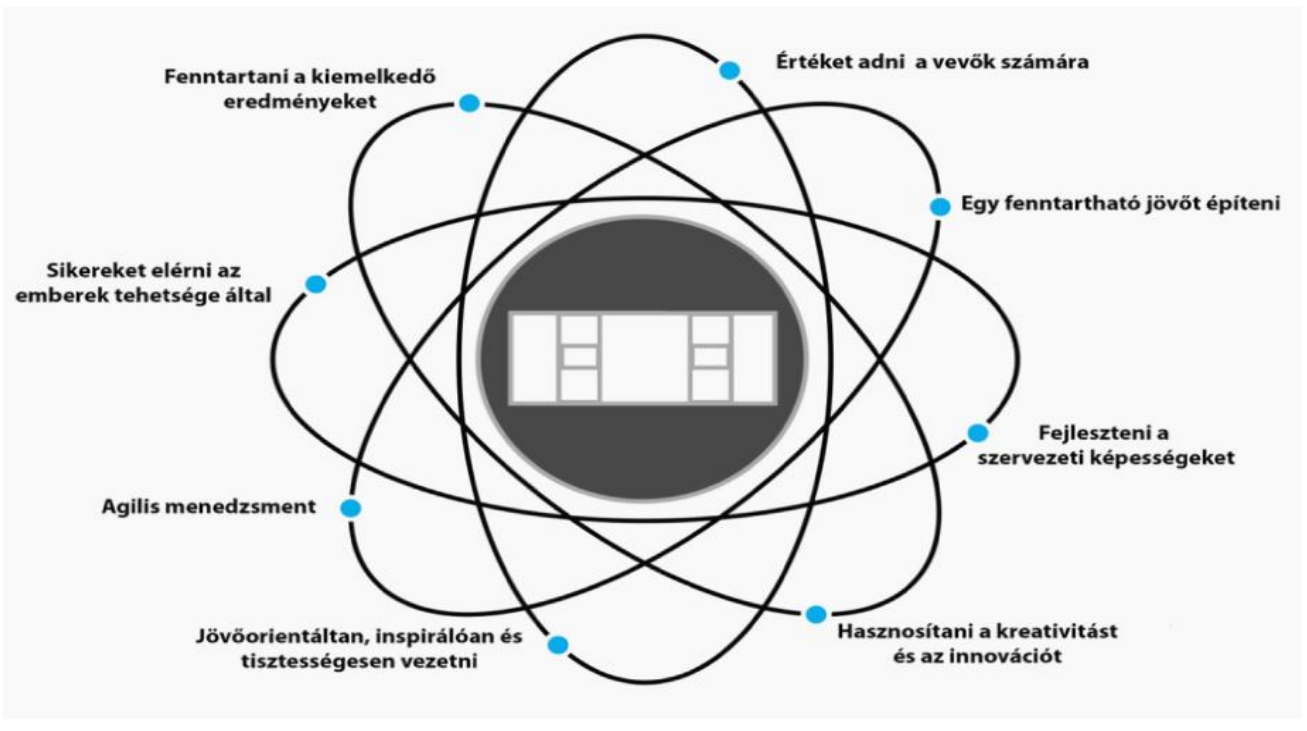

1. ábra: Kiválóság Alapelvek

(Forrás: EFQM Keretrendszere, 2013, Szövetség a Kiválóságért Közhasznú Egyesület)

Az EFQM modell nyolc alapelve:

Az értékelés a 8 alapelvnek való megfelelést vizsgálja valamennyi szervezetben, így a felsőoktatási intézményekben is.

Az EFQM Kiválóság Modell egy keretrendszer, amely segít az intézményeknek a Kiválóság Alapelveket és a RADAR logikát átültetni a gyakorlatba. 


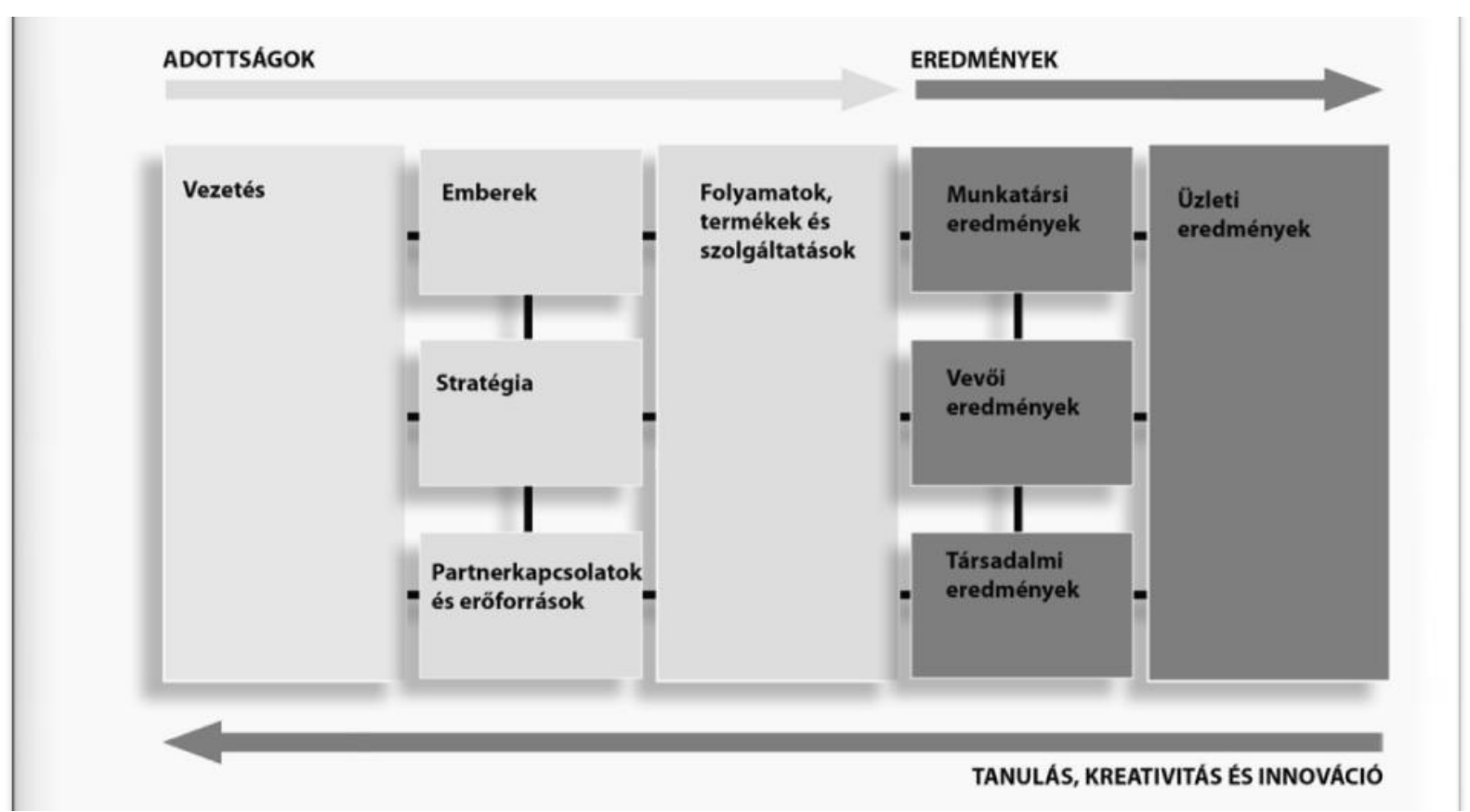

2. ábra: EFQM modell

(Forrás: EFQM Keretrendszere, 2013, Szövetség a Kiválóságért Közhasznú Egyesület)

RADAR logika egy dinamikus értékelési keretrendszer, amely egyben egy erőteljes vezetési eszköz is. Azzal segíti a fenntartható kiválóság megvalósítása iránt elkötelezett intézményeket, hogy kijelöli a cél érdekében leküzdendő kihívásokat.

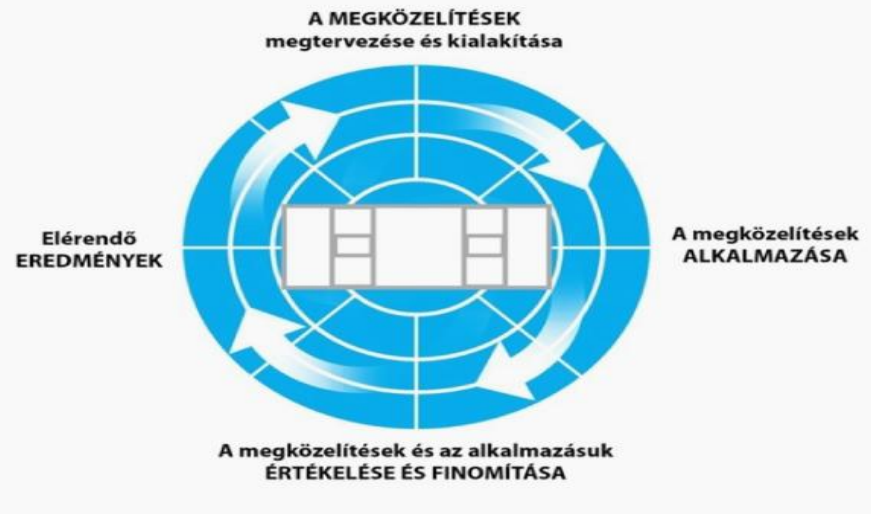

3. ábra: RADAR logika

(Forrás: EFQM Keretrendszere, 2013, Szövetség a Kiválóságért Közhasznú Egyesület)

A megfelelő alkalmazás esetén az EFQM Modell a RADAR logikával és a Kiválóság Alapelvekkel együtt biztosítja, hogy az intézmény által használt valamennyi vezetői gyakorlat egy olyan egységes rendszert alkosson, amelyet folyamatosan fejlesztenek, és amely segít megvalósítani a szervezet által kitűzött stratégiát. 
A Kiválóság Alapelvek felvázolják azt az alapot, amely a fenntartható kiválóság megvalósításához szükséges bármely intézmény esetében.

Az EFQM Kiválóság Modell lehetővé teszi a vezetők számára, hogy megértsék az ok-okozati összefüggéseket a szervezet tevékenysége és az elért eredményei között. A RADAR logika segítségével bármely intézmény kiválósági foka mérhető.

A vezetés, mint EFQM kritérium definíció: A kiváló szervezeteknek olyan vezetői vannak, akik alakítják a jövőt, tesznek azért, hogy az megvalósuljon, mindenkor követendő példát mutatnak az értékek és etikai alapelvek terén, valamint megteremtik a bizalom légkörét. Rugalmasak és képessé teszik a szervezetet, hogy kellő időben jelezzen előre és reagáljon a folyamatos sikeresség érdekében.

- 1.a. A vezetők kialakítják a szervezet küldetését, jövőképét, értékrendjét és etikai alapelveit, és példaként szolgálnak.

- 1b. A vezetők meghatározzák, nyomon követik, felülvizsgálják és ösztönzik a szervezet irányítási rendszerének és teljesítményének fejlesztését.

- 1c. A vezetők szoros kapcsolatot tartanak fenn a külső érintettekkel.

- 1d. A vezetők megerősítik a Kiválóság kultúráját a munkatársakkal közösen.

- 1e. A vezetők biztosítják, hogy a szervezet rugalmasan és hatásosan menedzselni a változásokat.

1a. A vezetők kialakítják a szervezet küldetését, jövőképét, értékrendjét és etikai alapelveit, és példaként szolgának.

A kiváló szervezetek vezetői:

- biztosítják a szervezet jövőjét azon alapvető cél meghatározásával és kommunikálásával, amely az átfogó jövőkép, küldetés, értékrend, etikai alapelvek és a szervezeti viselkedés alapjául is szolgál.

- kiállnak a szervezeti értékek mellett, és követendő példaként szolgálnak a tisztesség, a társadalmi felelősségvállalás és az etikus viselkedés terén a szervezeten belül és azon kívül egyaránt, a szervezet hírnevének és megítélésének javítása érdekében.

- kijelölik és kommunikálják az egyértelmű irányvonalat és a stratégiai fókuszt; összefogják munkatársaikat a szervezet küldetésének, jövőképének és céljainak megosztása és elérése érdekében.

- kialakítanak és támogatnak egyfajta megosztott vezetői szerepvállaláson alapuló szervezeti kultúrát, valamint felülvizsgálják és továbbfejlesztik a személyes vezetői magatartás hatékonyságát.

1b. A vezetők meghatározzák, nyomon követik, felülvizsgálják és ösztönzik a szervezet irányítási rendszerének és teljesítményének fejlesztését.

A kiváló szervezetek vezetői:

- a fejlődés nyomonkövetése érdekében meghatározzák és alkalmazzák a kiegyensúlyozott eredmények rendszerét, hosszú és rövid távú prioritásokat felmutató képet vetítenek a kulcs érintettek elé és kezelik az elvárásaikat.

- értik és továbbfejlesztik a szervezet alapvető képességeit.

- értékelik az elért eredményeket a jövőbeli teljesítmény javítása és az érintettek számára nyújtandó haszon fenntarthatósága érdekében. 
- döntéseiket tényszerű, megbízható információkra alapozzák, és minden elérhető ismeretet felhasználnak a meghatározó folyamatok jelenlegi és előre jelzett teljesítményének értelmezéséhez.

- elérik az érdekelt felek nagyfokú bizalmát azáltal, hogy hatékony mechanizmusokat alkalmaznak a jövőbeli forgatókönyvek megértése és a stratégiai, működési és pénzügyi kockázatok hatékony kezelése céljából.

1c. A vezetők szoros kapcsolatot tartanak fenn a külső érintettekkel.

A kiváló szervezetek vezetői:

- módszereket alkalmaznak a kulcsfontosságú érintettek különböző igényeinek és elvárásainak megismerésére, előrejelzésére és elvárásainak megismerésére, előrejelzésére és az ezekre történő reagálásra.

- kialakítják a közös értékeket, az elszámoltathatóságot, az etikai alapelvek, valamint a bizalom és nyitottság kultúráját a teljes értékláncon keresztül.

- a teljesítményük átlátható és elszámoltatható az érintett felek és a széles társadalom számára, valamint biztosítják, hogy a munkatársaik etikusan, felelősségteljesen és tisztességesen dolgozzanak.

- gondoskodnak a kulcsfontosságú érdekelteknek - beleértve a megfelelő felügyeleti testületeket is szóló pénzügyi és nem-pénzügyi beszámolók átláthatóságáról, figyelembe véve elvárásaikat.

- bátorítják az érintett feleket a szélesebb társadalom számára hasznos tevékenységekben való részvételre.

1d. A vezetők megerősítik a Kiválóság kultúráját a munkatársakkal közösen.

A kiváló szervezetek vezetői:

- inspirálják a munkatársakat, és megteremtik a bevonás, a tulajdonosi szemléletet, a felhatalmazás, a fejlesztés és az elszámoltathatóság kultúráját a tevékenységeiken, a viselkedésükön és a gyakorlatukon keresztül.

- felismerik, hogy az elért előnyöket úgy tudják fenntartani, hogy a vezetők képesek gyorsan tanulni és szükség esetén gyorsan reagálni.

- támogatják a munkatársakat terveik, céljaik és célkitűzéseik elérésében.

- az erőfeszítéseket és az eredményeket időben és megfelelő módon ismerik el.

- olyan szervezeti kultúrát hoznak létre, amely támogatja az új ötletek generálását és az újszerű gondolkodásmódot az innováció és a szervezeti fejlődés előmozdítása érdekében.

- elősegítik és bátorítják az esélyegyenlőséget és a sokszínűséget.

1e. A vezetők biztosítják, hogy a szervezet rugalmasan és hatásosan menedzselni a változásokat.

A kiváló szervezetek vezetői:

- rugalmasak; bizonyítják, hogy képesek megalapozott, gyors döntéseket hozni a rendelkezésre álló információk, a korábbi tapasztalatok és tudás alapján, a lehetséges hatások figyelembevételével.

- referenciának tekintik az „Ember, Bolygó és Nyereség” hármas pillért, miközben egyensúlyba hozzák az időnként egymásnak ellentmondó követelményeket, melyekkel szembesülnek.

- bevonnak minden fontos érintettet, és kérik a változtatásokhoz szükséges támogatásukat és együttműködésüket a szervezeti siker biztosítása érdekében. 
- hatékonyan kezelik a változásokat a strukturált projektmenedzsmenten és a folyamatfejlesztéseken keresztül.

- a kreatív ötletek generálására és priorizálására jól strukturált módszert alkalmaznak.

- a legígéretesebb ötleteket tesztelik és finomítják, valamint erőforrásokat biztosítanak a megfelelő időtartamon belüli megvalósításukhoz.

\section{A lehetséges vizsgálati modell}

A szakirodalmak áttanulmányozása után a számos kutatási módszerek közül az általam ismertetett mérési módszereket választottam a felméréseim alapjául. Úgy vélem, hogy a három mérési módszer együttes használata segíthet a vezetői viselkedés és tulajdonságok azonosításában, melyek hozzájárulhatnak a felsőoktatási intézmények versenyképességének növelésében, fenntartásában.

A mérésem során mind a három mérési módszert célszerű alkalmazni, és a következő csoportokat célszerű kialakítani: rektori vezetés, dékánok, tanszékvezetők és a kancellária vezetése. Célom, hogy melyek azok a vezetői attitűdök, melyek a hozzájárulhatnak a felsőoktatási intézmény sikeres működéséhez.

A mérési modellt a következő ábra szemlélteti:

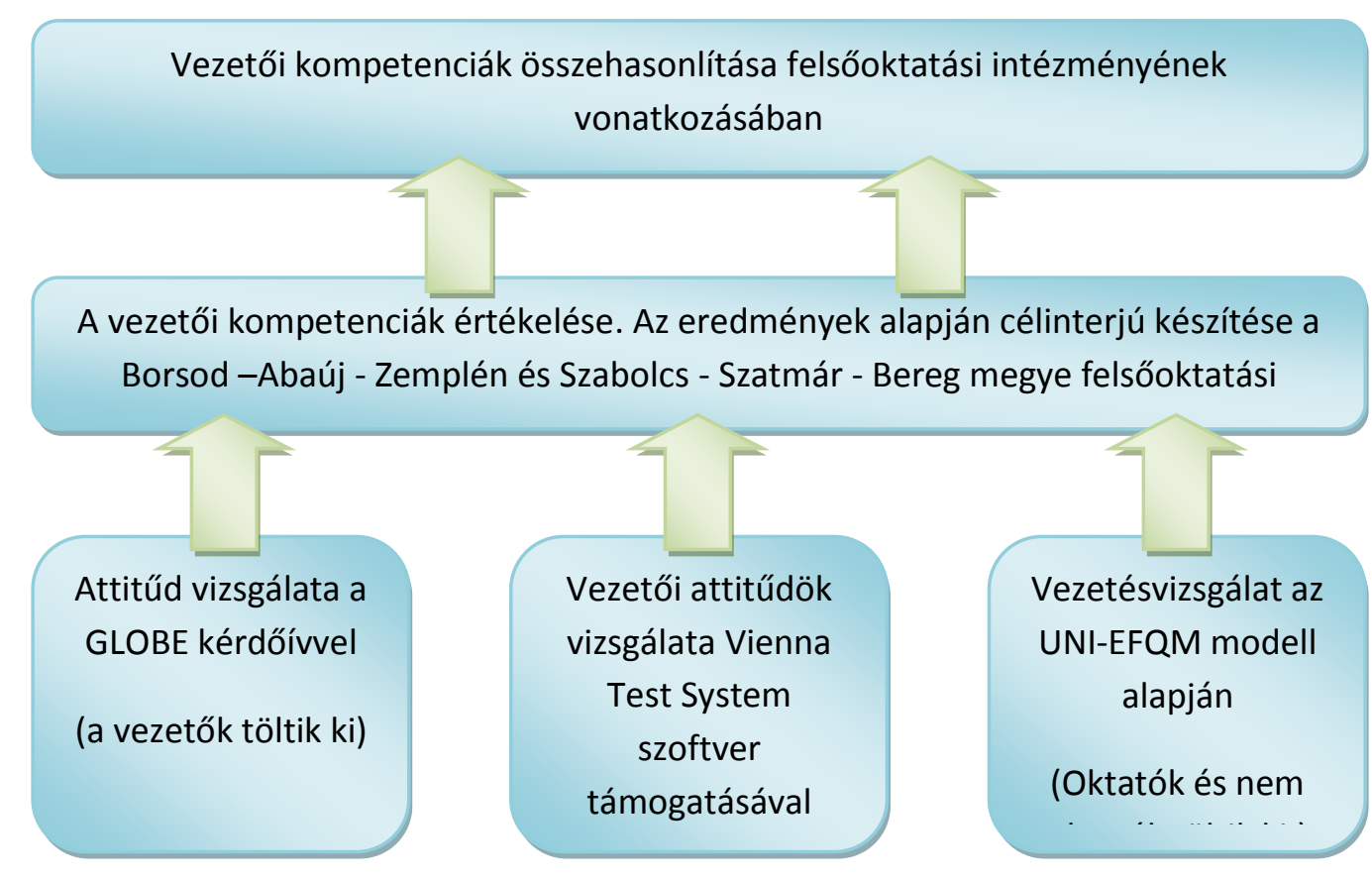

4. ábra: Mérési modell modell

(Forrás: Saját szerkesztés)

Kutatásaimban a Debreceni Egyetem a vezetés mérésére egyfelől a GLOBE (Global Leadership and Organizational Behavior Effectiveness) nemzetközi kérdőívet kívánjuk alkalmazni, másfelől a kompetenciák árnyaltabb differenciálására a világszintem piacvezető tesztrendszert a Vienna Test 
Systemet. Méréseinket kiegészítjük a felsőoktatási intézményekre kialakított szervezeti önértékelést lehetővé tevő UNI-EFQM modell vezetés vizsgálat blokkjával.

\section{Hivatkozások}

[1] MN. Abd Ghafar (2003), Rekabentuk Tinjauan Soal Selidik Pendidikan, Universiti Teknologi Malaysia: Penerbit UTM 3

[2] Gy. Bakacsi (1996), Szervezeti magatartás és vezetés, Közgazdasági és Jogi Könyvkiadó, Budapest

[3] Gy. Bakacsi, S. Takacs, Honnan - hova? A nemzeti es szervezeti kultúra változásai a kilencvenes évek közepének Magyarországán, Vezetéstudomány. 29 évfolyam 2. szám

[4] Szövetség a Kiválóságért Közhasznú Egyesület (1998), EFQM Keretrendszere, 2013

[5] K. Barakonyi (2009), Egyetemi kormányzás Magyarországon, Kézirat, PTE KTK, Pécs

[6] R. Boam, P. Sparrow (1992), Designing and Achieving Competency, London: McGraw-Hill

[7] C. Chapparo, J. Ranka (1997), Occupational Performance Model (Australia): A description of constructs and structure, megtekintve: 2014. május 24. <http://www.occupationalperformancecm/constructs.pdf>

[8] YS. Choi, JS. Kim, BW. Lee (2000), Public's Perception and Judgment on Nuclear Power, Annals of Nuclear Energy, vol. 27, 295-309.

[9] DN. Den Hartog, et al. (1997), Dutch and Polish Perceptions of Leadership and Culture: The GLOBE Project, European Journal of Work and Organizational Psychology, 6(4), pp. 387413.

[10] Dewan Bahasa Dan Pustaka, Kamus Dewan Bahasa Dan Pustaka Kuala Lumpur - Bahasa Melayu Ke Bahasa Melayu, Kuala Lumpur (2005, Dewan Bahasa Dan Pustaka

[11] Gy. Fábri (főszerk.) (2005), Egyetemek mérlegen - hallgatói vélemények, Educatio, Budapest

[12] A. Grosz, J. Rechnitzer (szerk.) (2005), Régiók és nagyvárosok innovációs potenciálja Magyarországon, Magyar Tudományos Akadémia Regionális Kutatások Központja, PécsGyőr

[13] G. Hamel, CK. Prahalad (1994), Competing for the Future. Cambridge, MA: Harvard Business School Press

[14] R.J. House, M. Javidan (2004), Overview of GLOBE. In: House, R.J. et al. (eds.): Culture, Leadership and Organizations - The GLOBE Study of 62 Societies, Sage Publication, London, pp. 9-26.

[15] I. HRrubos (2006), A 21. század egyeteme - Egy új társadalmi szerződés felé, Educatio, 15. évf. 4. pp. 665-681. 
[16] A. Karácsonyi (2006), A leadership, a szervezeti kultúra és kapcsolatuk jellegzetességei a magyar szervezetek esetében, $\mathrm{PhD}$ értekezés, Budapesti Corvinus Egyetem

[17] I. Lengyel (2003), Verseny és területi fejlődés: Térségek versenyképessége Magyarországon, JATEPress, Szeged

[18] J. Liu, A. Gentle (2005), Survey of Vocational and Technical Education (VTE): Participation

[19] M. Losoncz (2007), A lisszaboni folyamat hozzájárulása Magyarország versenyképességének javulásához, In: Farkas B. (szerk.), A lisszaboni folyamat és Magyarország, SZTE Gazdaságtudományi Kar Közleményei 2007, JATEPress, Szeged, pp. 94-102.

[20] OECD (2007), Drivers for Regional Engagement. Chapter 2., In Higher Education and Region, Globally competitive, locally engaged, Paris, pp. 29-43.

[21] J. Rechnitzer (2010), A felsőoktatás regionalitása, a régiók és a felsőoktatás, In: Törőcsik M. - Kuráth G. (szerk.), Egyetemi marketing, Marketing a felsőoktatásban, Pécsi Tudományegyetem, Pécs

[22] KL. Smart, JJ. Cappel (2006), Students' Perceptions of Online Learning: A Comparative Study, Journal of Information Technology Education, vol. 5, pp. 202-219.

[23] L. Spencer, S. Spencer (1993), Competence at work, New York: Wiley

[24] E. Szűcs, S. Kovács, T. Balla (2015), Vezetői kompetenciák és az intézmény versenyképessége, Miskolc - Lillafüred, „Mérleg és Kihívások” IX. NEMZETKÖZI TUDOMÁNYOS KONFERENCIA, ISBN 978-963-358-098-1 